Gray, Patty A. 2000. "Chukotkan Reindeer Husbandry in the Post-Socialist Transition," Polar

Research, Vol.19, No.1, pp. 31-38.

POLAR RESEARCH 19(1), pp.31-37 (June 2000)

\title{
Chukotkan reindeer husbandry in the post-socialist transition ${ }^{1}$
}

\section{Patty A. Gray}

\begin{abstract}
Chukotkan reindeer husbandry in the post-socialist transition. Patty A. Gray. Reindeer herding in the Chukotka Autonomous Okrug, as in many other regions across the Russian North, has been experiencing a progressive collapse since the dissolution of the Soviet Union in 1991. The collapse is typically blamed on Russia's privatization program, which broke up collectivized reindeer farms into supposedly privatized enterprises. While this process did indeed bring significant changes to the practice of reindeer herding in Chukotka, this paper argues that a more fundamental issue is the political and economic change at the local level that most likely makes the collapse irreversible. According to the rhetoric of the new "democratic" framework, the majority rules, and their priorities take precedence. As a result, the indigenous peoples and their priorities - chief among which is reindeer herding - have been squeezed into the political margins. This has been exacerbated by the development of a relationship of internal colonialism between dominant urban Russians and village-dwelling indeigenous reindeer herders, which has led to greater inequalities between the two groups as the Russians monopolize both resources and power in the region.
\end{abstract}

Max Planck Institute for Social Anthropology, Postfach 1103 51, 06017 Halle (Saale), Germany.

\section{Introduction: Chukotka and Internal Colonialism}

The goals of this article are to briefly trace the political-economic changes occurring in Russia since 1991 that have affected reindeer herding in Chukotka, and to illustrate the impacts of these changes on reindeer herding communities in Chukotka. While it is expected that many commonalities will be found across the political-territorial regions of Russia's North where reindeer herding occurs, this paper will also reveal what is unique to Chukotka, both in the manner in which federal policies were implemented there, as well as in the ways reindeer herding communities have been affected by and have responded to the changes. I will argue that 
the ongoing progressive collapse of post-Soviet reindeer herding in Chukotka is probably irreversible, and this is not due primarily to ecological change, or to the currently poor management strategies, nor even necessarily of Russia's federal privatization program. Rather, the specific manifestation at the local level of these political-economic changes that began in 1991 and continued through the decade of the 1990s have created circumstances under which herding cannot survive.

While a strong political and social legacy from the Soviet period may still be felt in Chukotka (the new post-Soviet political elite most certainly includes old Communist elites), there is at the same time a radical change in the conduct of local politics and inter-ethnic relations that has serious consequences for the practice of reindeer herding, among other things. Following the collapse of the Soviet Union, Russia’s regions gained greater autonomy from Moscow, and these regions are now struggling for power vis-a-vis the center and one another. Chukotka has self-consciously developed many of the trappings of a self-determining state, including a developing core-periphery relationship between its capital city and its tundra region. This is an uneven relationship in which the core dominates and exploits the periphery. A useful concept for understanding these conditions in Chukotka is one that was developed in large part by Latin American scholars: that of internal colonialism (cf. Schindler 1991). This theory perhaps gained its widest appreciation after the publication of Michael Hechter's 1975 study of Irish-English relations, Internal Colonialism: The Celtic Fringe in British National Development, but it has significant precursors in scholars such as Rene Dumont, Frantz Fanon, C. Wright Mills and Pablo Gonzalez Casanova, as well as in the writings of Lenin and Gramsci (Hechter 1975:8; see also Havens and Flinn 1970 for a useful overview).

According to Hechter (1975:9), internal colonialism is embodied in the unequal 
distribution of resources and power between two groups that results from spatially uneven development ("modernization") in a given territory. These conditions apply to post-Soviet Chukotka in the very clear inequalities between Natives1 (Chukchi, Chuvans, Koriaks, Evens and others) and non-Native immigrants (mostly Russians and Ukrainians, known locally as "Incomers"). As market forces have trickled into Chukotka, they have favored city-dwelling Incomers who have greater access to investment capital through their links to western Russian (which is nicknamed "the mainland"). Virtually all of Chukotka's entrepreneurs engaged in retail or industries such as gold mining or commercial fisheries are Incomers. Natives (most of whom are village-dwelling) are primarily relegated to non-entrepreneurial pursuits: education and scholarship, cultural professions such as museums, performing ensembles, native-language media, handicrafts, and the so-called "traditional economies" of sea mammal hunting and reindeer herding. While these (especially the latter two) were high-prestige (and relatively highsalary) occupations in the Soviet period, their status has plummeted in the post-socialist transformation. Very few Natives have succeeded in turning the new capitalist-leaning conditions to their economic advantage, even in commercial herding operations, and a great many have plummeted into outright poverty.

Hechter goes on to describe the conditions of internal colonialism thus:

The superordinate group ... attempts to regulate the allocation of social roles such that those roles commonly defined as having high prestige are reserved for its members. Conversely, individuals from the less advanced group are denied access to these roles (Hechter 1975:9).

Hechter calls this stratification a cultural division of labor:

Actors come to categorize themselves and others according to the range of roles each may be expected to play. They are aided in this

1 I am aware of the reservations felt by some towards using the term "native" because of its power to negatively essentialize groups that are in fact complex and diverse. The term "Native" as used here is what I consider to be the best translation of the term that the indigenous peoples of Chukotka most often used to refer to themselves: korennoi. 
characterization by the presence of visible signs, or cultural markers, which are seen to characterize both groups (ibid.).

This process of redefining the prestige of social roles has been occurring in Chukotka since the late 1980s, following the advent of perestroika and the opening of space for the reinterpretation of social relations. Native access to social roles was always strongly regulated in the Soviet Union; but the range of roles was somewhat more balanced with those of Incomers. Natives’ key role was always seen as bearers of "traditional culture,” but Natives as well as Incomers were encouraged to participate in politics. Participation in entrepreneurial economics, beyond the Party-dominated State economy, was not an option for either group during the Soviet period. Now that economic entrepreneurship is an option, that role has very quickly been usurped as the exclusive domain of Incomers.

Moreover, economic entrepreneurship has become one of the highest priorities in the new post-socialist Chukotkan society. Conversely, small-scale, formerly state-subsidized economies have become the lowest priority -- and foremost among these is reindeer herding. Reindeer herding is associated with Nativeness, and Nativeness is associated with economic dependency, not economic entrepreneurship. At the beginning of the post-socialist transition to a capitalist system, Native reindeer herders did indeed attempt to participate in economic entrepreneurship, as will be discussed below; but these attempts failed, and subsequently reindeer herding as a whole began its catastrophic collapse. The collapse of reindeer herding across the Russian North is generally blamed on the federal privatization program (initially implemented 1993-94 in Chukotka) and the concurrent disappearance of state-supported markets with the collapse of the Soviet Union. These are significant factors, indeed; although the root causes are more likely to be found in Soviet era changes made to the practice of reindeer herding. More importantly for the present argument, blaming privatization obscures the more complex factors of ongoing, local 
political and economic change that preclude the likelihood of arresting this collapse of reindeer herding.

I argue that the attempts at entrepreneurship failed largely because the dominant Incomers were engaged in internal colonialism as defined by Hechter -- categorizing the social roles that Natives and Incomers could be expected to play, and monopolizing the political and economic roles. In the changing cultural division of labor, Natives were increasingly categorized by Incomers as cultural icons, utterly irrelevant to economic development except perhaps as a kind of Chukotkan trademark. Incomers successfully categorized themselves as economic entrepreneurs, and they were entirely uninterested in investing their new-found capital in the reindeer herding industry, preferring instead to exploit the tundra for its mineral and biological resources. These conditions of internal colonialism are intimately connected with the transformation of local politics in Chukotka that began shortly after the collapse of the Soviet Union in 1991. Before examining this transformation, I will first briefly outline the privatization program as it was implemented in Chukotka and sketch some of the immediate outcomes for reindeer herding communities.

\section{The "Privatization" of Reindeer Herding}

The reorganization of reindeer herding enterprises in Chukotka into so-called “privatized" entities began in earnest in 1993, in response to a series of rather unclear and sometimes conflicting decrees issue by Russian President Boris El’tsin beginning in May 1991 (see Wegren 1994 for a summary). In general, all state farms and collective farms in Russia were expected to reregister themselves either as one of several proposed new forms of collectivized agriculture, or as individual private farms. Farm members were expected to hold a meeting and 
vote on the form they wanted their farm to take. These votes occurred all across Chukotka in the course of 1993-94, and resulted in a wide variety of outcomes.

I visited two neighboring reindeer herding collective farms along the Anadyr' River in 1998 that represented two differing outcomes. The members of the "State Farm First Revolutionary Committee of Chukotka” in the village of Ust'-Belaia (pop. about 1200) essentially did not want to change a thing, and their reorganization amounted to nothing more than a name change (merely adding the words "Farming Enterprise" to the front of the full existing name. This farm in 1998 was considered one of the strongest, and its survival was typically credited to its refusal to change its basic collective structure. The members of the "State Farm Anadyrskii” in the village of Snezhnoe (pop. about 375), 18 kilometers upriver, were divided on the question. Most chose to remain with the farm; one enterprising brigade was keen to strike out on its own under the leadership of its long-time Chukchi brigadier, and it split from the main farm, taking a portion of farm land and property with it (this former brigadier is now director of the main collective). A couple of families (both consisting of mixed Native/nonNative marriages) simply withdrew themselves from the farm altogether, choosing to focus on building up their own family farmsteads within the village, unconnected in any way to reindeer herding. In other villages in Chukotka, whole state farms were broken up this way into small, individual enterprises, leaving no core collective at all. In nearly all cases, these are the farms undergoing greatest crisis today.

This period of reorganization stirred quite a bit of excitement in Chukotka; local newspapers carried story after story of enterprising Native reindeer herders who were heroically striking out on their own. They were treated as pioneers; some doubted their chances, others lauded their courage in striking out into uncharted territory - private enterprise was daring 
enough, and Natives attempting it seemed doubly adventurous. Even for those farms that chose to retain a collectivized structure, there was a great stir over the division of the farms' assets into shares and the distribution of a portion of these shares to each farm member. In theory, a member could "cash out" his or her shares at any time, receiving rubles and/or farm property as compensation.

In reality, most of the individual enterprises failed within one or two years, and the shares proved to be worthless to all but those who cashed in their shares immediately. The latter were often Incomers who received farm equipment (such as tractors or trucks), which they sold as quickly as possible and left the region for "the mainland". These individuals were regarded with bitterness by remaining villagers as traitors who had pilfered the farm of its assets. In fact, I often heard people make a play on the Russian word for privatization - privatizatsiia - using instead the invented word prikhvatizatsiia, which borrows meaning from the verb prikhvatit', "to seize” or “to pilfer”. In some parts of Chukotka, herds of reindeer were taken over by Incomers with no herding experience whatsoever, and in these cases deer were quickly converted to cash, after which the former owner of the herd left the region or moved on to a more lucrative enterprise, such as retail sales or gold mining. This could occur because, again, Incomers were categorized as entrepreneurs, and if reindeer herding was to become an entrepreneurial enterprise, then they should be able to have a crack at it.

\section{The Subsequent Collapse of Reindeer Herding}

The most immediate effect of "privatization" experienced by the women and men whose livelihoods came from reindeer herding was the sudden disappearance of their paychecks. Prior to reorganization, their salaries as tent-workers and herders had been paid regularly by the state, 
and my consultants often recalled how they had always had plenty of cash for their basic needs and more. After reorganization, salaries were to be paid out of the profits earned by the herding enterprise, and that of course meant no salaries - reindeer herding had always operated in the red, depending heavily on state subsidies to keep the whole thing afloat, and capitalist rhetoric was not enough to turn a subsistence economy into a profit-making enterprise. This precipitated hardship for reindeer herding families, who in the absence of cash had to begin relying more heavily on locally harvested fish, berries, mushrooms, pine nuts, hunted caribou, and domestic deer meat. Poaching of fur-bearing animals increased, since skins could be sold for dollars. A complicating factor that negatively affected reindeer herding was a rather drastic demographic shift that was occurring throughout Chukotka, affecting every place from the cities down to the most remote tundra camps. Following the collapse of the Soviet Union, many Incomers to Chukotka began returning to their home regions in the more temperate zones of Russia (see Heleniak 1997 for an overview of migratory shifts in Russia during this time). This exaggerated the "peripheralness" of Chukotka’s reindeer herding villages, as Incomers vacated their top tier professional positions in the collective farm administration. Many of these positions simply remained vacant, since the farms could no longer offer salaries. As tundra workers grew weary of working under increasing hardships created by the removal of the state supports they had been raised on, they opted to move into the depopulated villages to seek any work they could find, from stoking coal in the heating plant to clerical work in the mayor's office. Such jobs were outside of the farm's jurisdiction (either in the utility company or in the village administrative apparatus), and this meant they would earn the worker a more-or-less regular paycheck, rather than promises of dividends someday when the reindeer operation eventually became profitable. This demographic shift meant a stressful period of rapid social change in the village, and it 
contributed to a collapse in the structure of reindeer management.

This latter collapse, along with other factors, helped precipitate the catastrophic crash in the domestic reindeer head counts in Chukotka, which were relatively stable until about 1993 (see Table 1 and Figure 1). Besides the loss of herding personnel to village jobs, there has been a rather sudden die-off of elder male Native herders - the very individuals who possessed the greatest knowledge of herd management. These deaths were most likely precipitated by worsening health care and nutrition, and in some cases were the result of suicide (such a case occurred while I was resident in Snezhnoe). The remaining herders represent far less accumulated experience, and the stresses of loss and hardship have made them susceptible to depression, which fosters alcoholism and suicide, domestic violence and homicide. This downward spiral has been matched by the decline in reindeer head counts since 1989. Deer have been lost to accidents and poor management decisions, to predation by bear or wolves, and to herds of wild deer (caribou, known locally as dikary [dee-kah-REE]) that lead away domestic deer.

\section{TABLE 1. Reindeer Head Counts in Chukotka,1958-1998}

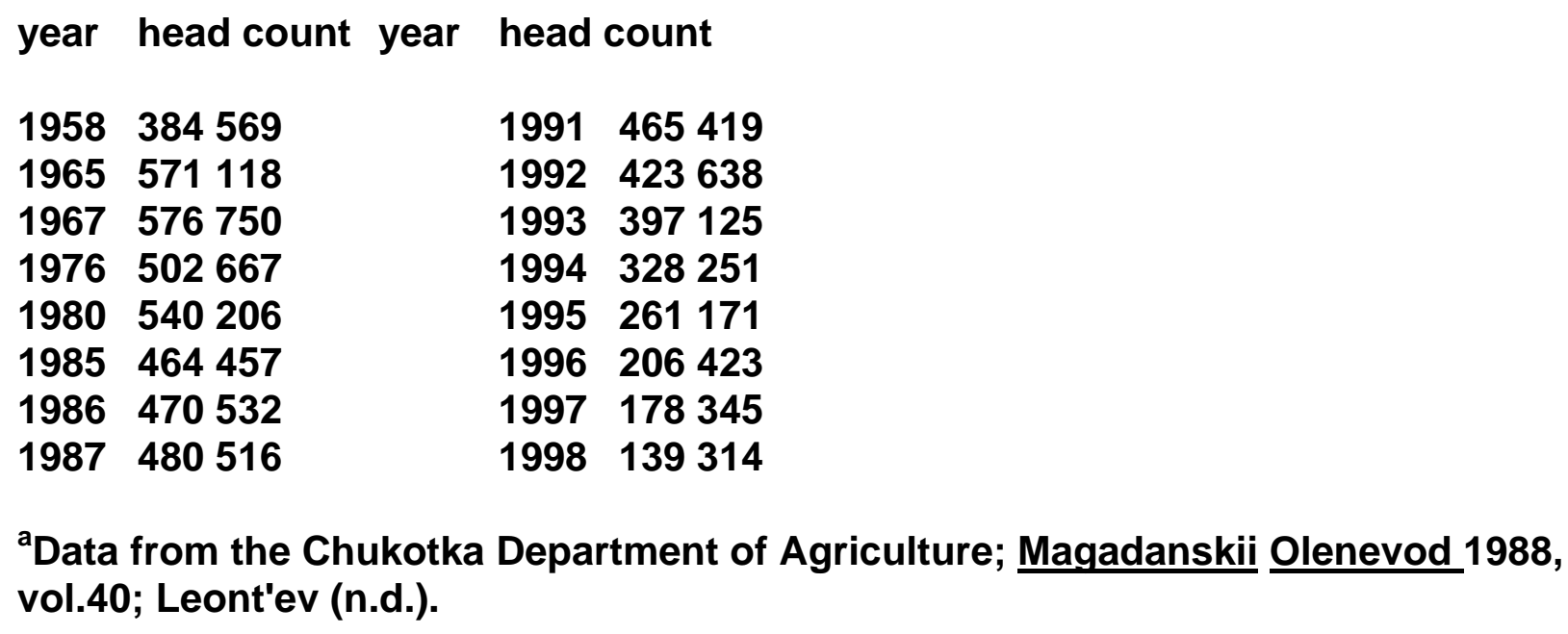

Dikary are considered a particular menace. The reindeer of Chukotka are represented by 
two strains of Rangifer tarandus: a domesticated strain that has been husbanded by Native Chukchi and Chuvan herders for many hundreds of years; and the dikary that migrate primarily on north-south routes in Chukotka's western tundra region. While technically these two populations are the same species, local observers insist that the wild deer are larger and more robust than domesticated deer and can never be tamed. Domestic deer that are led away by dikary may be recaptured by a skilled herder, but if the domestic deer has been with a wild herd long enough, it cannot be reincorporated into a domestic herd. No one knows exactly how many dikary there are - estimates range from 35000 to 150 000. While the exact count is not agreed upon, everyone I interviewed expressed the sense that their numbers were growing, to the detriment of domestic deer.

As both people and deer have been lost, farm brigades have been merged over and over. For example, the farm in Snezhnoe that once boasted 12 brigades, each with a herd of about 2000 deer, had only four brigades in 1996, and by the time I returned in 1998, it was down to only two brigades with less than 1000 deer each. Even Ust'-Belaia has had to merge brigades in recent years. The people who remain in the tundra to tend them are in essence families, descended from some of the original families who owned the herds that first made up the state farm in Snezhnoe. In the case of one of these brigades, the younger family members remain in the tundra out of reverence for their elderly widowed Chukchi mother, who has lived with the herd all of her life, barely speaks any Russian, and staunchly refuses to leave the tundra while she still has a breath in her body. Once she has passed away, there will perhaps be little motivation for this family to stay with their herd.

\section{The Transformation of Local Politics in Chukotka}


The current crisis in reindeer herding is not merely a result of the ill-fated privatization program, but also a casualty of the deliberate jettisoning by Russian leaders of any idea of the support of exclusively Native interests -- of which reindeer herding is a key manifestation -- as a regional priority. Under the legacy of Lenin's nationality policy, the "flowering" of all Soviet "nationalities" (from Ukrainians to Tatars to Chukchis) was encouraged not only culturally, but in terms of political and class consciousness (Slezkine 1994). Today the potentially revolutionary political component of that image has been removed, in what clearly appears as a radical and hasty abandonment by then-and-now dominant Russians of any pretense to building a multi-ethnic, shared society. Chukotka was originally created as one of several "national districts," intended (at least ideologically) as a kind of ethnic homeland for indigenous peoples there. Native elites groomed for politics occupied many local government positions, and the same was true for other ethnically-based territorial formations across the Soviet Union. However, while the privatization program was in the process of being implemented in Chukotka, regional politics was also undergoing transformation.

In 1991, Russian President Boris El'tsin personally appointed heads of administration (now called "governors") in each of Russia's 89 regions, deliberately choosing pro-democracy faithfuls in order to edge out the power of Communists in the regions (Sakwa 1993:183). This process had the net effect of a kind of political ethnic cleansing in government, since El'tsin's appointees were often Russians or Ukrainians, rather than representatives of indigenous ethnic groups. The same is true of locally-elected politicians. Chukotka's regional legislature was initially divided about half and half between Native deputies and Incomer deputies; but that ratio has since dropped, until by 1998 there were only two Native deputies out of the 14. Incomers see no problem in this; there has developed a pervasive rhetoric that, since Chukotka is now a 
democracy and in a democracy the majority rules, it is only right that government should reflect the majority population, which is non-Native (Natives comprise about 20\% of Chukotka's population, up from about $10 \%$ in the Soviet period due the outmigration discussed above). However, Natives see this as a disturbing development; they feel that they are being squeezed out of participation in the mainstream of their own home region and into a kind of cultural ghetto at the margins of Chukotkan society. There is no place for them in politics, and neither is there a place in entrepreneurial economics. Rather than being viewed as revolutionary political actors, as they were during the Soviet period, they are being recast as mere cultural icons of the new Chukotka. Lip service is paid to the need to develop reindeer herding, but actions have so far been superficial, stop-gap measures, such as delivering a few snowmobiles with great pomp and publicity. These measures seem designed primarily to preserve enough of an image of reindeer herding as an ongoing traditional pursuit in Chukotka to make it serviceable for media appeal both locally and back in Moscow, where Chukotka's governor openly seeks to draw greater attention to Chukotka for commercial investment purposes. The iconic image of the Chukchi reindeer herder, clad in fur clothing and standing benignly in the tundra (an image often found on the pages of the regional newspaper) is a convenient symbol for marketing the region. The Re-Nationalization of Reindeer Herding

The latest development in the crisis of Chukotkan reindeer herding was the announcement by the governor of a plan to re-nationalize all reindeer herding enterprises in Chukotka. The details of the re-nationalization plan itself were still in the planning stages by the end of 1998. The governor's initial proposal was for every form of reindeer herding enterprise in Chukotka - from those that remained joint, collective entities to those that broke off as small, private farms and still survive today - to hand over $51 \%$ of their assets to the administration. In 
return, the administration would "take care of" them, providing assistance in purchasing equipment, paying salaries, marketing reindeer products, etc. My Native consultants were all somewhat mystified as to what such a change might portend; some expressed optimism about it, while others expressed suspicion. There was some speculation that the administration was primarily interested in hedging its bets against the possibility of Russia once and for all clarifying rules for the sale of land; if this plan were implemented, the administration would in effect own the controlling share of virtually all land in Chukotka.

The governor announced this new plan at the Third Congress of Reindeer Herders in March 1998 - which, significantly, was not convened by the Native-run Union of Reindeer Herders of Chukotka, but by the governor himself. Native consultants told me stories of reindeer herder delegates being brought in from villages across Chukotka, presented with gifts and cash, and wined and dined in Anadyr's finest restaurant and its only casino. The Congress was one of three similar events staged by the administration within the space of five months, each a case of the administration convening an assembly of Native peoples that paralleled already existing Native-run organizations (the other two were an Assembly of Native Lesser-Numbered Peoples in November, which by-passed the authority of the Association of Native Lesser-Numbered Peoples of Chukotka; and the Congress of Sea Mammal Hunters, which ignored the Union of Sea Mammal Hunters).

These assemblies appeared to be full-frontal efforts by the administration to co-opt the agenda of Native peoples in Chukotka, a strategy that Havens and Flinn (1970:13) discuss as a typical feature of internal colonialism. A struggling Native movement has been tenaciously maintained among the urban elite in Anadyr'; while it has been able to accomplish little locally, it has begun to seek allies beyond Chukotka and to lobby for intervention by the federal 
government and concerned foreign partners. The recently increasing interest of the Chukotkan administration in reindeer herding appears to be a pro-active response to this potentiallythreatening politicization of the issue of reindeer herding. Reindeer herding is thus caught in the nexus of this wider struggle between state elites and Native elites for the power to represent Native interests in Chukotka, and is being made a pawn, one more symbol of Nativeness that can be manipulated by the dominant Incomers.

\section{Conclusion}

There has been a great deal of concern expressed in the scholarly community for the threat to cultural survival that the collapse of "traditional" practices of reindeer herding represents for Native peoples. Such concern is appropriate; but it should be complemented by a recognition of the extent to which reindeer herding has already been politicized in Russia. How "traditional” has reindeer herding been in the years of Soviet rule, since it was essentially destroyed, reinvented in collectivized form, and artificially supported by state subsidies? "Privatization” pulled out the last supports, and of course a collapse resulted; re-nationalization promises to return those supports, but will probably only create a facade of concern, and in any case will probably come too late.

Those of us who study reindeer herding wish to help, to somehow find solutions to stem this ongoing crisis. In order to do that, however, we must concurrently study and understand the transforming state and its power, and the position of Native peoples within that power, or all efforts to "help" will be futile. Some of the suggested approaches -- developing markets for reindeer products, providing entrepreneurial training for reindeer managers, etc. - would have no affect whatsoever without a radical restructuring of local government, and that is unlikely in 
Chukotka in the near future. Solutions will be difficult to devise; the place to begin is to recognize the agency of Native peoples and work to place more control over their fate in their own hands.

${ }^{1}$ ACKNOWLEDGEMENTS. This paper is based on the author's research in Chukotka in 1995-96 supported by a 1995-96 U.S. Department of Education Fulbright-Hayes Doctoral Dissertation Research Abroad Fellowship and a 1995-96 Individual Advanced Research Opportunities Research Residency for Eurasian Russia from the International Research and Exchanges Board (IREX), and additional research in 1998 supported by the National Science Foundation's Arctic Social Sciences program ("Regional Problems and Local Solutions in the Post-Soviet Transition: A Pilot Study to Assess the Problems Faced by Reindeer Herding Communities in the Chukotka Autonomous Okrug," award \#OPP-9726308, PI Peter Schweitzer, Co-PIs Patty A. Gray and Michael Koskey). I am grateful for Arjun Guneratne's suggestion that I look into Hechter's internal colonialism model as a way to understand current phenomena in Chukotka. My subsequent review of literature revealed that Debra Schindler also made this connection earlier (Schindler 1991). Thanks to Gail Osherenko and Igor Krupnik for constructive and extremely useful comments, which, nonetheless, do not remove from the author responsibility for any errors or misjudgements found in this paper. 


\section{References}

Havens, A. Eugene and Flinn, William L. (eds.). 1970: Internal colonialism and structural change in Colombia. Praeger Special Studies in International Economics and Development. New York: Praeger Publishers.

Hechter, Michael. 1975: Internal colonialism: The Celtic fringe in British national development, 1536-1966. Berkeley: University of California Press.

Heleniak, Timothy. 1997: Internal migration in Russia during the economic transition. PostSoviet Geography and Economics 38(2), 81-104.

Leont'ev, V. V. (n.d.): Osobennosti kul'turno-khoziastvennogo razvitiia narodnostei Chukotki na sovremennom etape (1958-1967 gg.): Okonchatel'nyi otchet. Magadan: Severo-Vostochnyi Kompleksnyi Nauchno-Issledovatel'skii Institut. (Particularities of the cultural-economic development of the peoples of Chukotka in the contemporary stage (1958-1967): Final Report. Magadan: North-East Interdisciplinary Scientific Research Institute.)

Sakwa, Richard. 1993: Russian politics and society. New York: Routledge.

Schindler, Debra. 1991: Theory, Policy, and the Narody Severa. Anthropological Quarterly 64, 68-74.

Slezkine, Yuri. 1994: Arctic mirrors: Russia and the small peoples of the north. Ithaca: Cornell University Press. 